\section{Keeping tobacco cheap: how tobacco companies undermine government tax measures}

\author{
Ruth E Malone
}

Tobacco taxation is widely acknowledged to be among the most effective tobacco-control measures. ${ }^{1}$ Higher tobacco taxes reduce consumption, discourage initiation and, when so earmarked, provide revenue to help support public health programmes. But for tobacco taxes to accomplish all three goals, they must be effectively implemented.

As Hiscock and colleagues demonstrate in this issue, ${ }^{2}$ even when tobacco taxes are increased regularly, tobacco companies cleverly undermine them using a variety of strategies. These include introducing cheaper products, changes in pack sizes, price-marking and undershifting, where companies absorb at least temporarily the difference in price so that consumers experience little to no change when taxes increase (and thus are less likely to try to quit as a result of the tax increase). As their analyses show, this undershifting is especially focused on the lower-cost segments of the market.

As smoking is increasingly concentrated among lower-income populations in many countries, this insidious undershifting is likely to further impoverish and worsen health disparities among poorer individuals, while rendering still richer some of the wealthiest corporations in the world. ${ }^{3}$ Tobacco control remains a social justice issue in every respect. Governments should take measures to prohibit such manipulative practices.

While some of these industry strategies are precluded under the EU Tobacco

Correspondence to Professor Ruth E Malone, Social and Behavioral Sciences, University of California, San Francisco, California 94118, USA; ruth.malone@ucsf.edu
Products Directive and in countries with standardised packaging legislation such as the UK, this research shows why countries not subject to these policies must design their tobacco taxes with an eye to anticipating how the tobacco industry will seek to undermine and minimise their effects on end users. This may require innovation in tax design. For example, beyond standardising pack sizes, governments could require minimum floor prices at the consumer level that would effectively preclude undershifting, prohibit introduction of cheaper products not previously on the market and ban price promotions and discounts, couponing and other similar mechanisms used by the industry to sustain cheap tobacco products. Ensuring that alternatives such as roll-your-own tobacco are subject to consistent tax policies could also help counter the industry's tactics. Making the tax increases much larger and more unpredictable may also help make them more challenging to counter.

A potentially more effective (if politically challenging) approach would be to accompany every tax increase with other new policies further curtailing the range and number of tobacco retailers, prohibiting internet sales, funding effective denormalisation media campaigns and raising the age to purchase higher with each succeeding year. Combining substantially larger, more effectively implemented tax increases with retailer restriction or restructuring could more quickly advance countries towards the endgame for the tobacco epidemic. Governments need to provide consistent messaging about these deadly products because nothing in the behaviour of tobacco companies to date suggests any readiness to abandon their continuing quest to keep tobacco cheap, attractive and available everywhere.

Among advocates of vaping and some industry apologists, a favourite hashtag used to attack tobacco-control proponents is \#keepsmokingweneedthemoney. The idea behind the slogan is that the tobacco-control movement is not genuinely concerned about improving health or ending smoking, only about perpetuating itself. Absent the kinds of effective details and accompanying policies that will end the ability of tobacco companies to undermine effective tax measures and ensure that the taxes do indeed reduce smoking, governments risk looking more cynical than the public already believes them to be. Long term, continuing to allow the sale of deadly products on every corner, no matter how high the price, sends a mixed message that the industry is happy to exploit.

Funding The authors have not declared a specific grant for this research from any funding agency in the public, commercial or not-for-profit sectors.

Competing interests None declared.

Provenance and peer review Not commissioned; internally peer reviewed.

(C) Author(s) (or their employer(s)) 2018. No commercial re-use. See rights and permissions. Published by BMJ.

Check for updates

To cite Malone RE. Tob Control 2018;27:483.

Tob Control 2018;27:483.

doi:10.1136/tobaccocontrol-2018-054645

\section{REFERENCES}

1 Marquez PV. Taxation: Most effective but still the leastused tobacco control measure: The World Bank blog, 2017. http://blogs. worldbank.org/health/taxation-mosteffective-still-least-used-tobacco-control-measure

2 Hiscock R, Branston JR, McNeill A, et al. Tobacco industry strategies undermine government tax policy: evidence from commercial data. Tob Control 2018;27:488-97.

3 Callard C. Follow the money: how the billions of dollars that flow from smokers in poor nations to companies in rich nations greatly exceed funding for global tobacco control and what might be done about it. Tob Control 2010;19:285-90 